\title{
Statins and colorectal cancer
}

\author{
Paul Lochhead ${ }^{1}$ and Andrew T Chan ${ }^{2,3}$ \\ ${ }^{1}$ Gastrointestinal Research Group, Division of Applied Medicine, Institute of Medical Sciences, \\ University of Aberdeen, Aberdeen, United Kingdom \\ ${ }^{2}$ Channing Division of Network Medicine, Department of Medicine, Brigham and Women's \\ Hospital, and Harvard Medical School, Boston, MA \\ ${ }^{3}$ Division of Gastroenterology, Massachusetts General Hospital, Boston, MA
}

\begin{abstract}
The 3-hydroxy-3-methylglutaryl-coenzyme A (HMG-CoA) reductase inhibitors, more commonly referred to as statins, comprise a family of lipid-lowering drugs that are prescribed on a global scale on account of their demonstrated safety and efficacy in reducing mortality from cardiovascular disease. Beyond their potent pharmacologic inhibition of cholesterol biosynthesis, statins appear to have pleiotropic effects, including modulation of cell growth, apoptosis, and inflammation. Through modulation of these pathways, statins have the potential to influence a wide range of disease processes, including cancer. Much attention has focussed on the association between statins and colorectal cancer, raising the prospect that these well-tolerated compounds could form the basis of future chemopreventive strategies. Herein we review the epidemiologic, clinical, and pre-clinical data relevant to statins and colorectal neoplasia, and discuss the current status and future potential of statins as chemopreventive agents.
\end{abstract}

\section{INTRODUCTION: STATINS AND CANCER}

The 3-hydroxy-3-methylglutaryl-coenzyme A (HMG-CoA) reductase inhibitors, more commonly referred to as statins, were first identified in the 1970s by Japanese biochemist Akira Endo, ${ }^{1}$ and received market approval for the treatment of hypercholesterolemia in the late 1980 's. ${ }^{2}$ As a result of their proven efficacy in the primary and secondary prevention of cardiovascular mortality and stroke, ${ }^{3}$ statins have become one of the most widely-prescribed medications in the world. Approximately $11 \%$ of the U.S. population use statins, with prevalence rising to $44 \%$ in those over 65 years of age. ${ }^{4}$ Statins competitively inhibit HMG$\mathrm{CoA}$ reductase, which catalyses the rate-limiting step in the mevalonate pathway. ${ }^{5} \mathrm{By}$ preventing the conversion of HMG-CoA to mevalonate, statins potently reduce endogenous cholesterol synthesis, leading to a decrease in circulating low density lipoprotein (LDL)cholesterol. ${ }^{5}$ Independent of their lipid-lowering properties, statins appear to possess a variety of pleiotropic effects, including inhibition of cell proliferation, enhanced apoptosis, and modulation of inflammation, endothelial function, and angiogeneis. ${ }^{6,7}$ Indeed, some of

(C) 2012 The American Gastroenterological Association. Published by Elsevier Inc. All rights reserved.

Correspondence to: Dr Andrew T Chan, Associate Professor of Medicine, Massachusetts General Hospital, Gastrointestinal Unit, GRJ-722, 55 Fruit St, Boston, MA 02114, Tel: 617-726-2862, achan@ partners.org.

Publisher's Disclaimer: This is a PDF file of an unedited manuscript that has been accepted for publication. As a service to our customers we are providing this early version of the manuscript. The manuscript will undergo copyediting, typesetting, and review of the resulting proof before it is published in its final citable form. Please note that during the production process errors may be discovered which could affect the content, and all legal disclaimers that apply to the journal pertain.

Conflicts of interest: Dr Chan has consulted for Bayer Healthcare, Millennium Pharmaceuticals, and Pfizer Inc.

Disclaimer: The content is solely the responsibility of the authors. 
these additional actions are thought to contribute to their demonstrated cardioprotective benefit. $6,8,9$ Through these diverse mechanisms, statins have been hypothesized to influence a wide range of additional disease processes, including cancer.

A significant body of evidence suggests that statins might have a role in cancer chemoprevention. ${ }^{10,11}$ However, the association between statins and cancer risk has a rather chequered history. Following the market approval of statins, concerns were raised regarding the long-term safety of pharmacological cholesterol-lowering in humans, based largely upon observational data suggesting that non-cardiovascular mortality, including cancer, may be increased by low serum cholesterol levels. ${ }^{12,13}$ In retrospect, this association was probably largely explained by uncontrolled confounding and reverse causality, with low cholesterol being a consequence of occult malignancy. ${ }^{14,15}$ Anxieties over long-term statin use were further compounded by pre-approval studies that suggested statins were carcinogenic in rodents. ${ }^{16}$ Data from an early cardiovascular randomized controlled trial (RCT) of pravastatin, ${ }^{17}$ demonstrating an increased incidence of breast cancer in the treatment arm, and findings of a later case-control study, suggesting increased risk of breast and prostate cancer among statin users, ${ }^{18}$ did little to allay fears over statin safety.

A number of subsequent RCTs have, reassuringly, suggested a neutral effect of statin use on overall cancer risk. ${ }^{19-22}$ Furthermore, some, but not all, observational studies have raised the possibility of inverse associations between statins and overall cancer risk, ${ }^{23-25}$ and risks of specific cancers, including colorectal cancer. ${ }^{26-29}$ In this article, we review the experimental, epidemiologic, and clinical data relevant to statins and colorectal neoplasia, and discuss the current status and future potential of statins as chemopreventive agents.

\section{EXPERIMENTAL EVIDENCE: ANTICANCER MECHANISMS OF STATINS}

The interest in statins as modifiers of cancer risk spawned a large number of experimental studies examining the anti-neoplastic effects of statins in cellular and animal models of human cancer. ${ }^{10,11}$ Inhibition of HMG-CoA reductase by statins leads not only to a decrease in cholesterol synthesis, but also to reduced generation of other intermediates of the mevalonate pathway, including the non-sterol isoprenoids, farnesyl pyrophosphate (FPP) and geranylgeranyl pyrophosphate (GGPP). ${ }^{5}$ FFP and GGPP are required for posttranslational modification (isoprenylation), and biologic activity of a wide variety of cellular proteins, including the small GTPases RAS and RHO, ${ }^{11}$ which are strongly implicated in carcinogenesis. ${ }^{30,31}$ Modulation of isoprenylation appears to be a central mechanism through which statins exert their antiproliferative and pro-apoptotic effects. ${ }^{7,11}$ In addition, dysregulation of the mevalonate pathway may be causally implicated as a driver of neoplastic transformation and tumor progression, and this may partly explain the tumorselective effects of statins. ${ }^{32,33}$

A number of HMG-CoA reductase-independent mechanisms have also been proposed to account for the pleiotropic effects of statins, including antioxidant activity, ${ }^{34}$ and effects on cell adhesion, ${ }^{35,36}$ inflammation, ${ }^{8,37}$ immunoregulation, ${ }^{38}$ and angiogenesis. ${ }^{39}$ Experimental data support a role for statins as anti-neoplastic agents in the colon. Statins have been shown to exert growth inhibitory and pro-apoptotic effects in several human colorectal cancer cell lines in vitro, and in tumor xenograft models. ${ }^{40,41}$ The molecular mechanisms that account for the effect of statins on colorectal cancer cell growth and survival remain poorly understood; however, enhanced cellular oxidative stress, ${ }^{42}$ endoplasmic reticulum stress and autophagy, ${ }^{43}$ altered expression of apoptotic and proliferative signalling molecules, ${ }^{44,45}$ and modulation of the bone morphogenic protein signalling pathway, ${ }^{46}$ have all been implicated by experimental studies. In rodents, statins reduce the occurrence of azoxymethane-induced colonic neoplasia. ${ }^{40,47,48}$ Statins also appear to reduce polyp formation in the genetically- 
predisposed Min mouse; either alone, ${ }^{49}$ or synergistically with celecoxib. ${ }^{50}$ In vitro data also support a role for statins as adjuncts to chemotherapy in colorectal cancer. Recent experimental evidence suggests that simvastatin may overcome resistance to EGFR inhibition with cetuximab in $K R A S$-mutated colon cancer cells,,${ }^{51}$ and lovastatin has been shown to act through epigenetic mechanisms to reduce cancer cell 'stemness' and enhance chemosensitivity to 5 -fluorouracil. ${ }^{52}$ Considered together, experimental evidence provides biologically plausible roles for statins in

\section{STATINS AND COLORECTAL CANCER RISK IN RANDOMIZED TRIALS}

As a result of numerous large randomized controlled trials (RCTs) of lipid-lwering and major vascular events, a wealth of clinical data on statin use has accrued. Most statin RCTs have collected data on overall cancer incidence, while some studies have recorded sitespecific incidence. Thus, cardiovascular RCTs represent a valuable resource for assessing differences in cancer incidence between groups where statin use has been randomly assigned. Several tabular meta-analyses of RCT data, performed using differing inclusion criteria and methodologies, ${ }^{19,20}, 22,53$ concur that statin use over follow-up periods of around 4-6 years is not associated with an increase in overall cancer incidence. Whilst this is obviously reassuring, aggregate cancer risk does not address the possibility of differential effects of statin use on the risks of specific cancer types. In the PROSPER trial, ${ }^{54}$ for example, the observed reduction in cardiovascular risk was largely offset by an excess of gastrointestinal malignancies in those assigned to statin, compared to placebo. Although meta-analyses of colorectal cancer risk in cardiovascular RCTs face the limitation of a reduced number of studies with available site-specific cancer data, these metaanalyses have consistently failed to demonstrate an association between statins and colorectal cancer. ${ }^{20},{ }^{22},{ }^{53}$ Thus, the increased number of gastrointestinal cancers observed in the PROSPER trial may have arisen by chance. Most recently, the Cholesterol Treatment Trialists' (CTT) Collaboration published a meta-analysis of individual data from 175,000 participants in 27 statin RCTs, five of which were trials of more intensive vs. standard LDLlowering. ${ }^{55}$ Over a median follow up of 4.8 years, the number of incident colorectal cancers was not significantly different between those assigned to statin (or more statin) compared to controls (or less statin). Furthermore, there were no associations between overall cancer risk and duration of therapy, participant age, type of statin, or baseline LDL. ${ }^{55}$

One major criticism of cancer risk estimates from meta-analyses of statin RCTs is duration of follow up. The longest average follow-up in the cited meta-analyses was 5.9 years, ${ }^{53}$ with some meta-analyses including individual RCTs with only two years of follow-up, or less. ${ }^{19,20,22}$ Individually, a small number of studies have accumulated longer post-trial follow-up. The WOSCOPS primary prevention study, which randomized participants to pravastatin or placebo for 5 years, found no difference in colorectal cancer incidence between groups 10 years after the completion of the trial. ${ }^{56}$ Similarly, the Heart Protection Study found no difference in colorectal cancer incidence between those assigned to five years of simvastatin or placebo after cumulative follow-up of 11 years. ${ }^{57}$ The adenomacarcinoma sequence is postulated to take at least 10 years, and the initiation of colorectal neoplasia from normal mucosa may take even longer. Unless the effects of statins are restricted to advanced stages of colorectal neoplasia, it is likely that the majority of RCTs have insufficient follow-up to assess fully the potential beneficial or adverse effects of statins on colorectal carcinogenesis. Additionally, as secondary endpoints, data on cancer incidence and mortality are not systemically collected in cardiovascular RCTs, and may thus be subject to ascertainment bias. Given that many cardiovascular trials have been conducted in high-risk populations, competing risks also becomes an important potential source of bias; individuals randomized to placebo may die from major vascular events before they have had time to develop cancer. 


\section{OBSERVATIONAL STUDIES OF STATINS AND COLORECTAL CANCER}

Case-control studies are generally able to efficiently examine associations between remote exposures and risk of disease, while cohort studies can be valuable in dissecting timedependent associations between exposures and outcomes. A large number of observational studies have assessed the association between statin use and colorectal cancer (Table 1). Perhaps the most publicised and highly cited of these studies is the analysis by Poynter and colleagues, based on the Molecular Epidemiology of Colorectal Cancer study. ${ }^{26}$ This was the first well-powered case-control study of statins and colorectal cancer, including 1,953 cases and 2,015 controls derived from the population of northern Israel. Following adjustment for multiple potential confounders, Poynter and colleagues observed an impressive $43 \%$ reduction in colorectal cancer risk associated with at least 5 years of selfreported statin use. Interestingly, a subsequent genetic association study, performed in the same parent case-control study, demonstrated that a polymorphism in the HMG-CoA reductase gene modified the association between statins and colorectal cancer and was associated with lower LDL-cholesterol in both cases and controls. ${ }^{58} \mathrm{~A}$ nested case-control study in veterans with diabetes, including 6,080 colorectal cancer cases and 24,320 controls, demonstrated a more modest reduction in colorectal cancer risk (9\%) associated with statin use, but without significant dose or duration-dependent relationships. ${ }^{29}$ Furthermore, the protective association was limited to colon (not rectal) cancer in patients older than 65 years without a history of previous polyps. ${ }^{29}$ A German population-based case-control study, comprising 540 cases and 614 controls, demonstrated an inverse association between colorectal cancer risk and statin use of 1-4 years duration, but, interestingly, no additional risk reduction was observed for use beyond 5 years. ${ }^{27}$ In contrast, at least 12 case-control studies from the U.S., Europe, and Asia have reported no significant associations between statin use and colorectal cancer risk. ${ }^{23},{ }^{24},{ }^{59-68}$ Indeed, in a study conducted in the United Kingdom, using an electronic general practice prescribing database, an increased risk of colorectal cancer was associated with statin use of greater than 4 years. ${ }^{67}$ A limitation of these data is that case-control studies are particularly susceptible to recall bias, or biases arising from the selection of cases and controls. Moreover, in the case-control study of Poynter and colleagues, over two thirds of cases and controls were Ashkenazi Jews, ${ }^{26}$ potentially limiting the generalizability of the findings to other populations. ${ }^{20}$

Data from cohort studies are more limited. A retrospective cohort study conducted in a large U.S. veterans population, containing over 37,000 statin users, reported a 35\% reduction in colorectal cancer risk associated with statin use, and also found a significant decrease in risk with increasing statin dose. ${ }^{28}$ In combined analysis of prospectively-collected data from the Health Professionals Follow-up Study and Nurses' Health Study, statin use was not associated with overall colorectal cancer risk, although an inverse association was observed for rectal cancer risk $(\mathrm{RR}=0.59) .{ }^{69}$ Analysis of incident colorectal cancers over almost 11 years of follow up in the Women's Health Initiative revealed no difference in incidence according to statin use, but did report risk reduction of borderline statistical significance specifically associated with lovastatin use. ${ }^{70}$ Eight additional large cohort studies reported neither beneficial nor harmful associations between statins and colorectal cancer. ${ }^{25,71-77}$ Compared to case-control analyses, cohort studies are generally less vulnerable to recall and selection biases, but can be limited by sample size and insufficient follow-up time for incident cancers. Some cohort studies encompass less follow-up time than several of the statin RCTs. ${ }^{71,72,75}$

Among four meta-analyses that have included data from case-control and cohort studies, ${ }^{20,22,53},{ }^{78}$ one found no association between statin use and colorectal cancer risk, ${ }^{22}$ while three reported risk reductions of more modest magnitude (risk estimates 0.86$0.91){ }^{20,53,78}$ In two of these meta-analyses, a significant association between statin use and 
colorectal cancer risk was observed only in fixed effects models but not random effects models. ${ }^{20,53}$ The study by Poynter and colleagues ${ }^{26}$ appears to have been a major source of inter-study heterogeneity in the metaanalysis by Bonovas and colleagues, ${ }^{53}$ suggesting that it may represent an outlier. The Poynter study also appears to have been the driver of the protective association observed in the metaanalysis by Browning and colleagues; ${ }^{20}$ when this case-control study was excluded, the association between statin use and colorectal cancer was null.

The main limitation of both case-control and cohort studies is that they are prone to residual confounding by unmeasured exposures or behaviors that are associated with both statin use and colorectal cancer incidence. Indeed, evidence suggests that statin use is associated with higher socioeconomic status, ${ }^{79}$ NSAID use, ${ }^{62}$ and health conscious behaviors, such as multivitamin use and screening colonoscopy. ${ }^{62}$ While most observational studies adjust for use of aspirin and NSAIDs, which are consistently associated with lower colorectal cancer risk, information on cancer screening and other risk modifiers, such as physical activity, are not universally collected. Furthermore, residual confounding is impossible to exclude, even in the best-designed studies.

\section{STATINS AND POLYP PREVENTION}

Even short-term statin use may be sufficient to influence the evolution or progression of colorectal adenomas, the precursors to the vast majority of colorectal cancers (Table 2). In a retrospective analysis conducted in over 2,500 veterans with a history of colonoscopic polypectomy for adenomas, Siddiqui and colleagues demonstrated a $49 \%$ reduction in the incidence of recurrent adenomas, and a $29 \%$ reduction in the incidence of advanced adenomas, associated with continuous statin use over $3-5$ years. ${ }^{80}$ In a subsequent analysis of 231 individuals from the same population, ${ }^{81}$ significantly fewer adenomas, of smaller size, were observed at follow-up colonoscopy in individuals who had achieved $230 \%$ reduction in LDL-cholesterol, compared to those who had not, suggesting that lipidlowering, rather than statin use per se, may partly be responsible for the effect of statins on adenoma development and progression. ${ }^{81}$ An independent case-control study of 197 patients, also from a veterans population, found no association between statin use and adenoma recurrence over a median 3.4 years. ${ }^{82}$ Furthermore, a secondary analysis of data from three large colorectal adenoma chemoprevention trials, with a combined total of 2,915 subjects, failed to demonstrate any association between statin use, recurrent adenomas, multiple adenomas, or advanced adenomas. ${ }^{83}$ The prevalence of self-reported statin use was, however, low $(8.1 \%)$ across the three chemoprevention trials, limiting power for the posthoc analysis. ${ }^{83}$ Statin users comprised a much larger proportion (37\%) of participants in the Adenoma Prevention with Celecoxib (APC) trial. ${ }^{84}$ However, in a secondary analysis of APC trial data, Bertagnolli and colleagues found no evidence to support a chemopreventive effect of statin use over 5 years of follow-up. On the contrary, statin use of $>3$ years was associated with a $39 \%$ increased risk of adenomas. ${ }^{84}$ Although these data are derived from a RCT, statin use was self-selected. Nonetheless, this analysis represents the largest prospective study of statin use and incident adenomas. Furthermore, assessment of the association between statin use and study endpoints was a planned secondary analysis. ${ }^{84}$

\section{STATIN USE AFTER A DIAGNOSIS OF COLORECTAL CANCER}

Another high-risk group, in whom it may be possible to demonstrate benefit from statin use in shorter term studies, are individuals who have already developed colorectal cancer. In a retrospective cohort study of 1,309 male veterans with colorectal cancer, ${ }^{85}$ compared to nonusers, $>3$ years of pre-diagnosis statin use was associated with lower tumor stage, lower prevalence of metastases, and a higher frequency of proximal cancers. Survival analysis 
demonstrated more favorable 5-year cancer-specific survival in statin users compared to non-users. A significant limitation of this study was the inability to control for pre-diagnosis colorectal screening. In a randomized trial of adjuvant chemotherapy involving 842 patients with stage III colorectal cancer, prospective observational analysis of post-diagnosis statin use did not reveal any association with improved disease free, recurrence free, or overall survival. ${ }^{86}$ A randomized phase II trial of chemoprevention with atorvastatin, sulindac, or dietary fiber, conducted in individuals with resected colorectal cancer or advanced adenomas, also failed to demonstrate a protective effect of statin therapy. ${ }^{87}$ This study, which used rectal aberrant crypt foci as a surrogate endpoint, was, however, underpowered, with only 85 subjects randomized to each of the three interventions, or placebo. ${ }^{87}$

The safety of simvastatin as an adjunct to conventional chemotherapy for metastatic colorectal cancer has been demonstrated by a completed phase II trial, ${ }^{88}$ and a number of additional phase II and III studies are currently recruiting. ${ }^{89}$ The National Surgical Adjuvant Breast and Bowel Project (NSABP) P-5 study is actively enrolling patients with resected stage I and II colon cancer. Participants will be randomized to receive rosuvastatin or placebo for five years, and the effect of statin therapy on the incidence of adenomas, metachronous cancer, and colon cancer recurrence will be evaluated..$^{90}$

\section{STATINS AND COMBINATION CHEMOPREVENTION}

Even if statins, when used alone, are judged to be ineffective at reducing the risk of colorectal neoplasia, their use in combination with other agents, such as NSAIDs or aspirin, may still prove to be a successful chemopreventive strategy. ${ }^{91}$ Experimental evidence suggests that statins act synergistically with NSAIDs, and cyclooxygenase-2 (COX-2) inhibitors, to induce cell cycle arrest and apoptosis in human colorectal cancer cell lines. ${ }^{40,92}$ In an animal model, statins, in combination with NSAIDs or aspirin, markedly reduce the incidence and multiplicity of azoxymethane-induced colon tumors. ${ }^{47,93}$ In addition, atorvastatin greatly enhances the chemopreventive efficacy of celecoxib in the Min mouse model of familial adenomatous polyposis. 50

In the German population-based case-control study, ${ }^{27}$ combined use of statins and low-dose aspirin for at least 5 years was associated with a striking $62 \%$ reduction in the risk of colorectal cancer. However, five other case-control studies, ${ }^{26,60,62,63,65}$ and two large prospective cohort studies, ${ }^{69,77}$ reported a lack of interaction between NSAIDs, aspirin, or COX-2 inhibitors and statin use. Furthermore, in the secondary analysis of data from three large adenoma chemoprevention trials, no differences in the risk ratios were observed between strata of aspirin or NSAID use. ${ }^{83}$ The ongoing NSABP P-5 study clinical trial permits entry of patients already on aspirin, and a planned secondary analysis is assessment of potential effect modification of rosuvastatin by aspirin. ${ }^{90}$

\section{SUMMARY AND FUTURE PERSPECTIVES}

An abundance of experimental data has provided a variety of biologically plausible mechanisms through which statins might affect the initiation or evolution of colorectal neoplasia. Evidence from clinical studies is, however, conflicting. Studies supporting a chemopreventive role for statins in colorectal neoplasia are relatively few in number and are almost exclusively of retrospective observational design. While the magnitude of risk reduction observed in the case-control study of Poynter and colleagues was impressive, collective analysis of observational studies by meta-analysis suggests a more modest effect size. ${ }^{53,78}$ Collectively, the influence of statin use on colorectal cancer in cardiovascular RCTs appears neutral. Taken together with the null observational analysis of statin use in the APC trial, this has certainly dampened enthusiasm for statins as chemopreventive agents. It remains conceivable, however, that statin use for longer periods, at higher doses, in 
combination with other agents, or in genetically defined subgroups (such as those with HMG-CoA reductase gene polymorphisms), may influence the risk of colorectal neoplasia.

It has been argued that the duration of chemoprevention trials should be at least as long as the latency period of many cancers. ${ }^{94}$ Follow-up duration is a major shortcoming of prospective analyses of statins and colorectal neoplasia to date, and attempting to address the latency period of colorectal cancer represents a logistic and financial challenge to future studies. In addition, given that the prevalence of statin use is high among those likely to be target subjects for future statin chemoprevention trials, establishing and maintaining a statinfree control arm is likely to become increasingly difficult.

From a clinical practice perspective, at present, there is insufficient evidence to recommend the use of statins for colorectal cancer chemoprevention. However, follow-up will continue to accrue for statin users in prospective cohorts and participants of completed intervention studies. Future analyses, benefitting from more lengthy exposure to statins, and increased time at risk of colorectal cancer, may prove enlightening. The outcome of ongoing clinical studies of statins in high-risk populations for polyp prevention, and as adjuvant therapeutic agents, will be eagerly awaited.

\section{Acknowledgments}

Funding Support: Dr Lochhead is supported by a clinical academic fellowship from the Chief Scientist Office of the Scottish Government. Dr Chan is a Damon Runyon Clinical Investigator.

\section{REFERENCES}

1. Endo A, Tsujita Y, Kuroda M, et al. Inhibition of cholesterol synthesis in vitro and in vivo by ML-236A and ML-236B, competitive inhibitors of 3-hydroxy-3-methylglutaryl-coenzyme A reductase. European journal of biochemistry / FEBS. 1977; 77:31-36. [PubMed: 908337]

2. Grundy SM. HMG-CoA reductase inhibitors for treatment of hypercholesterolemia. The New England journal of medicine. 1988; 319:24-33. [PubMed: 3288867]

3. Baigent C, Keech A, Kearney PM, et al. Efficacy and safety of cholesterol-lowering treatment: prospective meta-analysis of data from 90,056 participants in 14 randomised trials of statins. Lancet. 2005; 366:1267-1278. [PubMed: 16214597]

4. National Center for Health Statistics. Health, United States, 2011: With Special Feature on Socioeconomic Status and Health. Hyattsville, MD: 2012.

5. Gazzerro P, Proto MC, Gangemi G, et al. Pharmacological actions of statins: a critical appraisal in the management of cancer. Pharmacological reviews. 2012; 64:102-146. [PubMed: 22106090]

6. Bonetti PO, Lerman LO, Napoli C, et al. Statin effects beyond lipid lowering--are they clinically relevant? European heart journal. 2003; 24:225-248. [PubMed: 12590901]

7. Ma S, Ma CC. Recent development in pleiotropic effects of statins on cardiovascular disease through regulation of transforming growth factor-beta superfamily. Cytokine \& growth factor reviews. 2011; 22:167-175. [PubMed: 21700485]

8. Antonopoulos AS, Margaritis M, Lee R, et al. Statins as anti-inflammatory agents in atherogenesis: molecular mechanisms and lessons from the recent clinical trials. Current pharmaceutical design. 2012; 18:1519-1530. [PubMed: 22364136]

9. Davignon J. Beneficial cardiovascular pleiotropic effects of statins. Circulation. 2004; 109:III39III43. [PubMed: 15198965]

10. Katz MS. Therapy insight: Potential of statins for cancer chemoprevention and therapy. Nature clinical practice.Oncology. 2005; 2:82-89.

11. Demierre MF, Higgins PD, Gruber SB, et al. Statins and cancer prevention. Nature reviews.Cancer. 2005; 5:930-942.

12. Oliver MF. Might treatment of hypercholesterolaemia increase non-cardiac mortality? Lancet. 1991; 337:1529-1531. [PubMed: 1675380] 
13. Kritchevsky SB, Kritchevsky D. Serum cholesterol and cancer risk: an epidemiologic perspective. Annual Review of Nutrition. 1992; 12:391-416.

14. Jacobs DR Jr. Muldoon MF, Rastam L. Invited commentary: low blood cholesterol, nonillness mortality, and other nonatherosclerotic disease mortality: a search for causes and confounders. American Journal of Epidemiology. 1995; 141:518-522. [PubMed: 7900718]

15. Sharp SJ, Pocock SJ. Time trends in serum cholesterol before cancer death. Epidemiology (Cambridge, Mass.). 1997; 8:132-136.

16. Newman TB, Hulley SB. Carcinogenicity of lipid-lowering drugs. JAMA : the journal of the American Medical Association. 1996; 275:55-60. [PubMed: 8531288]

17. Sacks FM, Pfeffer MA, Moye LA, et al. The effect of pravastatin on coronary events after myocardial infarction in patients with average cholesterol levels. Cholesterol and Recurrent Events Trial investigators. The New England journal of medicine. 1996; 335:1001-1009. [PubMed: 8801446]

18. Coogan PF, Rosenberg L, Palmer JR, et al. Statin use and the risk of breast and prostate cancer. Epidemiology (Cambridge, Mass.). 2002; 13:262-267.

19. Dale KM, Coleman CI, Henyan NN, et al. Statins and cancer risk: a meta-analysis. JAMA : the journal of the American Medical Association. 2006; 295:74-80. [PubMed: 16391219]

20. Browning DR, Martin RM. Statins and risk of cancer: a systematic review and metaanalysis. International journal of cancer.Journal international du cancer. 2007; 120:833-843. [PubMed: 17131313]

21. Bonovas S, Filioussi K, Tsavaris N, et al. Statins and cancer risk: a literature-based meta-analysis and meta-regression analysis of 35 randomized controlled trials. Journal of clinical oncology : official journal of the American Society of Clinical Oncology. 2006; 24:4808-4817. [PubMed: 17001070]

22. Kuoppala J, Lamminpaa A, Pukkala E. Statins and cancer: A systematic review and metaanalysis. European journal of cancer (Oxford, England: 1990). 2008; 44:2122-2132.

23. Blais L, Desgagne A, LeLorier J. 3-Hydroxy-3-methylglutaryl coenzyme A reductase inhibitors and the risk of cancer: a nested case-control study. Archives of Internal Medicine. 2000; 160:2363-2368. [PubMed: 10927735]

24. Graaf MR, Beiderbeck AB, Egberts AC, et al. The risk of cancer in users of statins. Journal of clinical oncology : official journal of the American Society of Clinical Oncology. 2004; 22:23882394. [PubMed: 15197200]

25. Friis S, Poulsen AH, Johnsen SP, et al. Cancer risk among statin users: a population-based cohort study. International journal of cancer.Journal international du cancer. 2005; 114:643-647. [PubMed: 15578694]

26. Poynter JN, Gruber SB, Higgins PD, et al. Statins and the risk of colorectal cancer. The New England journal of medicine. 2005; 352:2184-2192. [PubMed: 15917383]

27. Hoffmeister M, Chang-Claude J, Brenner H. Individual and joint use of statins and low-dose aspirin and risk of colorectal cancer: a population-based case-control study. International journal of cancer.Journal international du cancer. 2007; 121:1325-1330. [PubMed: 17487832]

28. Farwell WR, Scranton RE, Lawler EV, et al. The association between statins and cancer incidence in a veterans population. Journal of the National Cancer Institute. 2008; 100:134-139. [PubMed: 18182618]

29. Hachem C, Morgan R, Johnson M, et al. Statins and the risk of colorectal carcinoma: a nested case-control study in veterans with diabetes. The American Journal of Gastroenterology. 2009; 104:1241-1248. [PubMed: 19352344]

30. Pylayeva-Gupta Y, Grabocka E, Bar-Sagi D. RAS oncogenes: weaving a tumorigenic web. Nature reviews.Cancer. 2011; 11:761-774.

31. Rathinam R, Berrier A, Alahari SK. Role of Rho GTPases and their regulators in cancer progression. Frontiers in bioscience : a journal and virtual library. 2011; 17:2561-2571. [PubMed: 21622195]

32. Duncan RE, El-Sohemy A, Archer MC. Mevalonate promotes the growth of tumors derived from human cancer cells in vivo and stimulates proliferation in vitro with enhanced cyclin-dependent 
kinase-2 activity. The Journal of biological chemistry. 2004; 279:33079-33084. [PubMed: 15155733]

33. Clendening JW, Penn LZ. Targeting tumor cell metabolism with statins. Oncogene. 2012

34. Davignon J, Jacob RF, Mason RP. The antioxidant effects of statins. Coronary artery disease. 2004; 15:251-258. [PubMed: 15238821]

35. Weitz-Schmidt G, Welzenbach K, Brinkmann V, et al. Statins selectively inhibit leukocyte function antigen-1 by binding to a novel regulatory integrin site. Nature medicine. $2001 ; 7: 687-$ 692.

36. Wagner BJ, Lob S, Lindau D, et al. Simvastatin reduces tumor cell adhesion to human peritoneal mesothelial cells by decreased expression of VCAM-1 and beta1 integrin. International journal of oncology. 2011; 39:1593-1600. [PubMed: 21874229]

37. Malicki S, Winiarski M, Matlok M, et al. IL-6 and IL-8 responses of colorectal cancer in vivo and in vitro cancer cells subjected to simvastatin. Journal of physiology and pharmacology : an official journal of the Polish Physiological Society. 2009; 60:141-146. [PubMed: 20065508]

38. Smaldone C, Brugaletta S, Pazzano V, et al. Immunomodulator activity of 3-hydroxy-3methilglutaryl-CoA inhibitors. Cardiovascular \& hematological agents in medicinal chemistry. 2009; 7:279-294. [PubMed: 19663791]

39. Elewa HF, El-Remessy AB, Somanath PR, et al. Diverse effects of statins on angiogenesis: new therapeutic avenues. Pharmacotherapy. 2010; 30:169-176. [PubMed: 20099991]

40. Agarwal B, Bhendwal S, Halmos B, et al. Lovastatin augments apoptosis induced by chemotherapeutic agents in colon cancer cells. Clinical cancer research : an official journal of the American Association for Cancer Research. 1999; 5:2223-2229. [PubMed: 10473109]

41. Wachtershauser A, Akoglu B, Stein J. HMG-CoA reductase inhibitor mevastatin enhances the growth inhibitory effect of butyrate in the colorectal carcinoma cell line Caco-2. Carcinogenesis. 2001; 22:1061-1067. [PubMed: 11408350]

42. Qi XF, Kim DH, Yoon YS, et al. Involvement of oxidative stress in simvastatin-induced apoptosis of murine CT26 colon carcinoma cells. Toxicology letters. 2010; 199:277-287. [PubMed: 20883752]

43. Yang PM, Liu YL, Lin YC, et al. Inhibition of autophagy enhances anticancer effects of atorvastatin in digestive malignancies. Cancer research. 2010; 70:7699-7709. [PubMed: 20876807]

44. Guruswamy S, Rao CV. Synergistic effects of lovastatin and celecoxib on caveolin-1 and its downstream signaling molecules: Implications for colon cancer prevention. International journal of oncology. 2009; 35:1037-1043. [PubMed: 19787257]

45. Kaneko R, Tsuji N, Asanuma K, et al. Survivin down-regulation plays a crucial role in 3hydroxy-3-methylglutaryl coenzyme A reductase inhibitor-induced apoptosis in cancer. The Journal of biological chemistry. 2007; 282:19273-19281. [PubMed: 17472962]

46. Kodach LL, Bleuming SA, Peppelenbosch MP, et al. The effect of statins in colorectal cancer is mediated through the bone morphogenetic protein pathway. Gastroenterology. 2007; 133:12721281. [PubMed: 17919499]

47. Suh N, Reddy BS, DeCastro A, et al. Combination of atorvastatin with sulindac or naproxen profoundly inhibits colonic adenocarcinomas by suppressing the p65/beta-catenin/cyclin D1 signaling pathway in rats. Cancer prevention research (Philadelphia, Pa.). 2011; 4:1895-1902.

48. Yasuda Y, Shimizu M, Shirakami Y, et al. Pitavastatin inhibits azoxymethane-induced colonic preneoplastic lesions in C57BL/KsJ-db/db obese mice. Cancer science. 2010; 101:1701-1707. [PubMed: 20398056]

49. Teraoka N, Mutoh M, Takasu S, et al. Inhibition of intestinal polyp formation by pitavastatin, a HMG-CoA reductase inhibitor. Cancer prevention research (Philadelphia, Pa.). 2011; 4:445-453.

50. Swamy MV, Patlolla JM, Steele VE, et al. Chemoprevention of familial adenomatous polyposis by low doses of atorvastatin and celecoxib given individually and in combination to APCMin mice. Cancer research. 2006; 66:7370-7377. [PubMed: 16849589]

51. Lee J, Lee I, Han B, et al. Effect of simvastatin on cetuximab resistance in human colorectal cancer with KRAS mutations. Journal of the National Cancer Institute. 2011; 103:674-688. [PubMed: 21398618] 
52. Kodach LL, Jacobs RJ, Voorneveld PW, et al. Statins augment the chemosensitivity of colorectal cancer cells inducing epigenetic reprogramming and reducing colorectal cancer cell 'stemness' via the bone morphogenetic protein pathway. Gut. 2011; 60:1544-1553. [PubMed: 21551187]

53. Bonovas S, Filioussi K, Flordellis CS, et al. Statins and the risk of colorectal cancer: a metaanalysis of 18 studies involving more than 1.5 million patients. Journal of clinical oncology : official journal of the American Society of Clinical Oncology. 2007; 25:3462-3468. [PubMed: 17687150]

54. Shepherd J, Blauw GJ, Murphy MB, et al. Pravastatin in elderly individuals at risk of vascular disease (PROSPER): a randomised controlled trial. Lancet. 2002; 360:1623-1630. [PubMed: 12457784]

55. Emberson JR, Kearney PM, et al. Cholesterol Treatment Trialists' (CTT) Collaboration. Lack of effect of lowering LDL cholesterol on cancer: meta-analysis of individual data from 175,000 people in 27 randomised trials of statin therapy. PloS one. 2012; 7:e29849. [PubMed: 22276132]

56. Ford I, Murray H, Packard CJ, et al. Long-term follow-up of the West of Scotland Coronary Prevention Study. The New England journal of medicine. 2007; 357:1477-1486. [PubMed: 17928595]

57. Bulbulia R, Bowman L, et al. Heart Protection Study Collaborative Group. Effects on 11-year mortality and morbidity of lowering LDL cholesterol with simvastatin for about 5 years in 20,536 high-risk individuals: a randomised controlled trial. Lancet. 2011; 378:2013-2020. [PubMed: 22115874]

58. Lipkin SM, Chao EC, Moreno V, et al. Genetic variation in 3-hydroxy-3-methylglutaryl CoA reductase modifies the chemopreventive activity of statins for colorectal cancer. Cancer prevention research (Philadelphia, Pa.). 2010; 3:597-603.

59. Kaye JA, Jick H. Statin use and cancer risk in the General Practice Research Database. British journal of cancer. 2004; 90:635-637. [PubMed: 14760377]

60. Vinogradova Y, Hippisley-Cox J, Coupland C, et al. Risk of colorectal cancer in patients prescribed statins, nonsteroidal anti-inflammatory drugs, and cyclooxygenase- 2 inhibitors: nested case-control study. Gastroenterology. 2007; 133:393-402. [PubMed: 17681160]

61. Coogan PF, Rosenberg L, Strom BL. Statin use and the risk of 10 cancers. Epidemiology (Cambridge, Mass.). 2007; 18:213-219.

62. Coogan PF, Smith J, Rosenberg L. Statin use and risk of colorectal cancer. Journal of the National Cancer Institute. 2007; 99:32-40. [PubMed: 17202111]

63. Yang YX, Hennessy S, Propert K, et al. Chronic statin therapy and the risk of colorectal cancer. Pharmacoepidemiology and drug safety. 2008; 17:869-876. [PubMed: 18412290]

64. Boudreau DM, Koehler E, Rulyak SJ, et al. Cardiovascular medication use and risk for colorectal cancer. Cancer epidemiology, biomarkers \& prevention : a publication of the American Association for Cancer Research, cosponsored by the American Society of Preventive Oncology. 2008; 17:3076-3080.

65. Shadman M, Newcomb PA, Hampton JM, et al. Non-steroidal anti-inflammatory drugs and statins in relation to colorectal cancer risk. World journal of gastroenterology : WJG. 2009; 15:23362339. [PubMed: 19452574]

66. Robertson DJ, Riis AH, Friis S, et al. Neither long-term statin use nor atherosclerotic disease is associated with risk of colorectal cancer. Clinical gastroenterology and hepatology : the official clinical practice journal of the American Gastroenterological Association. 2010; 8:1056-1061. [PubMed: 20816860]

67. Vinogradova Y, Coupland C, Hippisley-Cox J. Exposure to statins and risk of common cancers: a series of nested case-control studies. BMC cancer. 2011; 11:409. [PubMed: 21943022]

68. Cheng MH, Chiu HF, Ho SC, et al. Statin use and the risk of colorectal cancer: a population-based case-control study. World journal of gastroenterology : WJG. 2011; 17:5197-5202. [PubMed: 22215945]

69. Lee JE, Baba Y, Ng K, et al. Statin use and colorectal cancer risk according to molecular subtypes in two large prospective cohort studies. Cancer prevention research (Philadelphia, Pa.). 2011; $4: 1808-1815$. 
70. Simon MS, Rosenberg CA, Rodabough RJ, et al. Prospective analysis of association between use of statins or other lipid-lowering agents and colorectal cancer risk. Annals of Epidemiology. 2012; 22:17-27. [PubMed: 22056480]

71. Jacobs EJ, Rodriguez C, Brady KA, et al. Cholesterol-lowering drugs and colorectal cancer incidence in a large United States cohort. Journal of the National Cancer Institute. 2006; 98:69-72. [PubMed: 16391373]

72. Setoguchi S, Glynn RJ, Avorn J, et al. Statins and the risk of lung, breast, and colorectal cancer in the elderly. Circulation. 2007; 115:27-33. [PubMed: 17179016]

73. Friedman GD, Flick ED, Udaltsova N, et al. Screening statins for possible carcinogenic risk: up to 9 years of follow-up of 361,859 recipients. Pharmacoepidemiology and drug safety. 2008; 17:2736. [PubMed: 17944002]

74. Singh H, Mahmud SM, Turner D, et al. Long-term use of statins and risk of colorectal cancer: a population-based study. The American Journal of Gastroenterology. 2009; 104:3015-3023. [PubMed: 19809413]

75. Flick ED, Habel LA, Chan KA, et al. Statin use and risk of colorectal cancer in a cohort of middleaged men in the US: a prospective cohort study. Drugs. 2009; 69:1445-1457. [PubMed: 19634923]

76. Haukka J, Sankila R, Klaukka T, et al. Incidence of cancer and statin usage--record linkage study. International journal of cancer.Journal international du cancer. 2010; 126:279-284. [PubMed: 19739258]

77. Jacobs EJ, Newton CC, Thun MJ, et al. Long-term use of cholesterol-lowering drugs and cancer incidence in a large United States cohort. Cancer research. 2011; 71:1763-1771. [PubMed: 21343395]

78. Taylor ML, Wells BJ, Smolak MJ. Statins and cancer: a meta-analysis of case-control studies. European journal of cancer prevention : the official journal of the European Cancer Prevention Organisation (ECP). 2008; 17:259-268. [PubMed: 18414198]

79. Thomsen RW, Johnsen SP, Olesen AV, et al. Socioeconomic gradient in use of statins among Danish patients: population-based cross-sectional study. British journal of clinical pharmacology. 2005; 60:534-542. [PubMed: 16236044]

80. Siddiqui AA, Nazario H, Mahgoub A, et al. The long-term use of statins is associated with a decreased incidence of adenomatous colon polyps. Digestion. 2009; 79:17-22. [PubMed: 19246916]

81. Siddiqui A, Nazario HE, Patel M, et al. Reduction in low-density lipoprotein cholesterol levels during statin therapy is associated with a reduced incidence of advanced colon polyps. The American Journal of the Medical Sciences. 2009; 338:378-381. [PubMed: 19794305]

82. Parker-Ray N, Barakat J, Roy PK, et al. Statin use does not prevent recurrent adenomatous polyp formation in a VA population. Indian journal of gastroenterology : official journal of the Indian Society of Gastroenterology. 2010; 29:106-111. [PubMed: 20658327]

83. Wei JT, Mott LA, Baron JA, et al. Reported use of 3-hydroxy-3-methylglutaryl coenzyme A reductase inhibitors was not associated with reduced recurrence of colorectal adenomas. Cancer epidemiology, biomarkers \& prevention : a publication of the American Association for Cancer Research, cosponsored by the American Society of Preventive Oncology. 2005; 14:1026-1027.

84. Bertagnolli MM, Hsu M, Hawk ET, et al. Statin use and colorectal adenoma risk: results from the adenoma prevention with celecoxib trial. Cancer prevention research (Philadelphia, Pa.). 2010; 3:588-596.

85. Siddiqui AA, Nazario H, Mahgoub A, et al. For patients with colorectal cancer, the long-term use of statins is associated with better clinical outcomes. Digestive diseases and sciences. 2009; 54:1307-1311. [PubMed: 19337834]

86. Ng K, Ogino S, Meyerhardt JA, et al. Relationship between statin use and colon cancer recurrence and survival: results from CALGB 89803. Journal of the National Cancer Institute. 2011; 103:1540-1551. [PubMed: 21849660]

87. Limburg PJ, Mahoney MR, Ziegler KL, et al. Randomized phase II trial of sulindac, atorvastatin, and prebiotic dietary fiber for colorectal cancer chemoprevention. Cancer prevention research (Philadelphia, Pa.). 2011; 4:259-269. 
88. Lee J, Jung KH, Park YS, et al. Simvastatin plus irinotecan, 5-fluorouracil, and leucovorin (FOLFIRI) as first-line chemotherapy in metastatic colorectal patients: a multicenter phase II study. Cancer chemotherapy and pharmacology. 2009; 64:657-663. [PubMed: 19169686]

89. http://www.clinicaltrials.gov

90. http://cancer.gov/clinicaltrials/NSABP-P-5

91. Zhou P, Cheng SW, Yang R, et al. Combination chemoprevention: future direction of colorectal cancer prevention. European journal of cancer prevention : the official journal of the European Cancer Prevention Organisation (ECP). 2012; 21:231-240. [PubMed: 22456425]

92. Xiao H, Zhang Q, Lin Y, et al. Combination of atorvastatin and celecoxib synergistically induces cell cycle arrest and apoptosis in colon cancer cells. International journal of cancer.Journal international du cancer. 2008; 122:2115-2124. [PubMed: 18172863]

93. Reddy BS, Wang CX, Kong AN, et al. Prevention of azoxymethane-induced colon cancer by combination of low doses of atorvastatin, aspirin, and celecoxib in F 344 rats. Cancer research. 2006; 66:4542-4546. [PubMed: 16618783]

94. Hennekens CH, Buring JE, Manson JE, et al. Lack of effect of long-term supplementation with beta carotene on the incidence of malignant neoplasms and cardiovascular disease. The New England journal of medicine. 1996; 334:1145-1149. [PubMed: 8602179] 
Table 1

Observational studies of statins and colorectal cancer risk

\begin{tabular}{|c|c|c|c|}
\hline $\begin{array}{l}\text { Author, } \\
\text { year }\end{array}$ & $\begin{array}{l}\text { Study } \\
\text { design } a\end{array}$ & Study description/population & Findings: point estimate $(95 \% \mathrm{CI})^{b}$ \\
\hline $\begin{array}{l}\text { Blais, } \\
2000\end{array}$ & $\mathrm{CC}$ & $\begin{array}{l}\text { Canadian administrative health } \\
\text { database. Statin use compared to use } \\
\text { of bile acid-binding resins in } 56 \text { colon } \\
\text { cancer cases and } 560 \text { controls }\end{array}$ & Colon cancer: $\mathrm{OR}=0.83(0.37-1.89)$ \\
\hline $\begin{array}{l}\text { Graaf, } \\
2004\end{array}$ & $\mathrm{CC}$ & $\begin{array}{l}\text { Dutch dispensing database. Nested } \\
\text { study containing } 292 \text { colon cancer } \\
\text { cases and } 148 \text { rectal cancer cases. }\end{array}$ & $\begin{array}{l}\text { Colon cancer: } \mathrm{OR}=0.87(0.48-1.57) \\
\text { Rectal cancer: } \mathrm{OR}=0.48(0.16-1.48)\end{array}$ \\
\hline $\begin{array}{l}\text { Kaye, } \\
2004\end{array}$ & $\mathrm{CC}$ & $\begin{array}{l}\text { UK General Practice Research } \\
\text { Database study containing } 25 \text { colon, } \\
\text { and } 23 \text { rectal cancer cases, and } 115 \\
\text { and } 49 \text { controls, respectively. }\end{array}$ & $\begin{array}{l}\text { Colon cancer: } \mathrm{OR}=1.0(0.6-1.7) \text { Rectal cancer: } \\
\mathrm{OR}=1.6(0.9-2.8)\end{array}$ \\
\hline $\begin{array}{l}\text { Friis, } \\
2005\end{array}$ & $\mathrm{RC}$ & $\begin{array}{l}\text { Danish population-based cohort. } \\
\text { Cancer incidence compared among } 12,251 \\
\text { stain users and non-users in a } \\
\text { base population of } 334,754 \text {. }\end{array}$ & Colorectal cancer: $\mathrm{RR}=0.85(0.65-1.11)$ \\
\hline $\begin{array}{l}\text { Poynter, } \\
2005\end{array}$ & $\mathrm{CC}$ & $\begin{array}{l}\text { Molecular Epidemiology of Colorectal } \\
\text { Cancer study conducted in northern } \\
\text { Israel and comprising } 953 \text { colorectal cancer } \\
\text { cases and 2,015 controls. }\end{array}$ & $\begin{array}{l}\text { Colorectal cancer: } \\
\text { Any use, OR }=0.53(0.38-0.74) \\
\text { Use for } \geq 5 \text { years, OR=0.55 }(0.40-0.74) \\
\text { Colon cancer: } \\
\text { Any use, unadjusted OR }=0.55(0.38-0.80) \\
\text { Rectal cancer: } \\
\text { Any use, unadjusted OR }=0.38(0.19-0.73)\end{array}$ \\
\hline $\begin{array}{l}\text { Jacobs }^{71} \\
2006\end{array}$ & $\mathrm{PC}$ & $\begin{array}{l}\text { Association of statin use and cancer in } \\
132,136 \text { participants of the Cancer } \\
\text { Prevention Study II Nutrition Cohort. }\end{array}$ & $\begin{array}{l}\text { Colorectal cancer: } \\
\text { Current use, } \mathrm{RR}=1.03(0.85-1.26) \\
\text { Current use of } 25 \text { years, } \mathrm{RR}=1.09(0.83-1.43)\end{array}$ \\
\hline $\begin{array}{l}\text { Setoguchi, } \\
2007\end{array}$ & $\mathrm{RC}$ & $\begin{array}{l}\text { Study of drug prescribing records for } \\
\text { an elderly population in Pennsylvania. } \\
\text { Cancer incidence in } 24,439 \text { statin initiators } \\
\text { compared to } 7,284 \text { initiators } \\
\text { of glaucoma medications. }\end{array}$ & Colorectal cancer: $\mathrm{HR}=0.96(0.70-1.31)$ \\
\hline $\begin{array}{l}\text { Hoffmeister, } \\
2007\end{array}$ & $\mathrm{CC}$ & $\begin{array}{l}\text { German population-based colorectal cancer } \\
\text { study. Statin and low dose } \\
\text { aspirin use assessed in } 540 \text { cases and } \\
614 \text { controls. }\end{array}$ & $\begin{array}{l}\text { Colorectal cancer: } \\
\text { Statin use, OR=0.65 }(0.43-0.99) \\
\text { Aspirin use, OR=0.77 }(0.55-1.07) \\
\text { Use of both drugs for } 25 \text { years, OR=0.38 } \\
(0.15-0.97)\end{array}$ \\
\hline $\begin{array}{l}\text { Coogan, } \\
2007\end{array}$ & $\mathrm{CC}$ & $\begin{array}{l}\text { U.S. population-based study of } 10 \text { cancers } \\
\text { containing } 734 \text { colorectal } \\
\text { cancer cases and } 3,900 \text { controls. }\end{array}$ & $\begin{array}{l}\text { Colorectal cancer: } \mathrm{OR}=0.8(0.5-1.2) \\
\text { Colon cancer: } \mathrm{OR}=0.7(0.4-1.1) \\
\text { Rectal cancer: } \mathrm{OR}=1.1(0.6-2.0)\end{array}$ \\
\hline $\begin{array}{l}\text { Coogan, } \\
2007\end{array}$ & $\mathrm{CC}$ & $\begin{array}{l}\text { Massachusetts population-based study } \\
\text { of colorectal cancer with } 1,809 \text { cases } \\
\text { and } 1,809 \text { controls. }\end{array}$ & $\begin{array}{l}\text { Colorectal cancer: } \\
\text { Any use, OR=0.92 }(0.78-1.09) \\
\text { Use for } \geq 10 \text { years, OR=0.86 (0.51-1.45) }\end{array}$ \\
\hline Vinogradova, ${ }^{60} 2007$ & $\mathrm{CC}$ & $\begin{array}{l}\text { Nested study in UK QResearch } \\
\text { general practice database. Statin use } \\
\text { compared among } 5,686 \text { colorectal } \\
\text { cancer cases and } 24,982 \text { controls. }\end{array}$ & $\begin{array}{l}\text { Colorectal cancer: } \\
\text { Any use, OR=0.93 }(0.83-1.04) \\
\text { Use for }>25 \text { months, OR=0.99 }(0.84-1.16)\end{array}$ \\
\hline $\begin{array}{l}\text { Farwell, } \\
2008\end{array}$ & $\mathrm{RC}$ & $\begin{array}{l}\text { New England Veterans Affairs } \\
\text { healthcare database. Cancer incidence } \\
\text { compared among } 37,248 \text { statin users } \\
\text { and 25,594 anti-hypertensive drug } \\
\text { users not taking statins. }\end{array}$ & $\begin{array}{l}\text { Colorectal cancer: } \\
\text { Any dose, } \mathrm{HR}=0.65(0.55-0.78) \\
\text { Low dose, } \mathrm{HR}=0.66(0.54-0.82) \\
\text { Medium dose, } \mathrm{HR}=0.63(0.50-0.81) \\
\text { High dose, } \mathrm{HR}=0.59(0.41-085)\end{array}$ \\
\hline $\begin{array}{l}\text { Friedman, } \\
2008\end{array}$ & $\mathrm{RC}$ & $\begin{array}{l}\text { Northern California health care } \\
\text { program database. Cancer incidence in } \\
361,859 \text { statins users compared to } \\
\text { non-users. }\end{array}$ & $\begin{array}{l}\text { Colon cancer: } \\
\text { Any use, HR=0.97 }(0.85-1.11) \\
\text { Use >5years, HR=1.02 }(0.75-1.38) \\
\text { Rectal cancer: } \\
\text { Any use, HR=0.97 }(0.76-1.25) \\
\text { Use for }>5 \text { years, HR }=1.15(0.66-2.01)\end{array}$ \\
\hline
\end{tabular}




\begin{tabular}{|c|c|c|c|}
\hline $\begin{array}{l}\text { Author, } \\
\text { year }\end{array}$ & $\begin{array}{l}\text { Study } \\
\text { design }^{a}\end{array}$ & Study description/population & Findings: point estimate $(95 \% \mathrm{CI})^{b}$ \\
\hline $\begin{array}{l}\text { Yang, } \\
2008\end{array}$ & $\mathrm{CC}$ & $\begin{array}{l}\text { Population-based study nested in UK } \\
\text { general practice research database, } \\
\text { containing } 4,432 \text { colorectal cancers } \\
\text { and } 44,292 \text { controls. }\end{array}$ & $\begin{array}{l}\text { Colorectal cancer: } \\
\text { Use for }>5 \text { years, } O R=1.1(0.5-2.2) \\
\text { Use for } 10 \text { years, } O R=1.3(0.6-2.7)\end{array}$ \\
\hline $\begin{array}{l}\text { Boudreau, } \\
2008\end{array}$ & $\mathrm{CC}$ & $\begin{array}{l}\text { Western Washington SEER cancer } \\
\text { registry used to identify } 665 \text { colorectal } \\
\text { cancer cases and } 665 \text { controls. }\end{array}$ & $\begin{array}{l}\text { Colorectal cancer: } \mathrm{OR}=1.02(0.65-1.59) \\
\text { Colon cancer: } \mathrm{OR}=0.91(0.55-1.50) \\
\text { Rectal cancer: } \mathrm{OR}=1.47(0.50-4.29)\end{array}$ \\
\hline $\begin{array}{l}\text { Flick, } \\
2009\end{array}$ & $\mathrm{PC}$ & $\begin{array}{l}\text { Statin use and colorectal cancer risk } \\
\text { evaluated in } 65,115 \text { participants in the } \\
\text { California Men's Health Study. }\end{array}$ & $\begin{array}{l}\text { Colorectal cancer: } \\
\text { Any use, HR=0.89 }(0.61-1.30) \\
\text { Use for } \geq 5 \text { years, HR=0.93 }(0.43-1.63)\end{array}$ \\
\hline $\begin{array}{l}\text { Hachem, } \\
2009\end{array}$ & $\mathrm{CC}$ & $\begin{array}{l}\text { Nested case-control study of veterans } \\
\text { with diabetes. Frequency of filled } \\
\text { statin prescriptions compared between } \\
6,080 \text { colorectal cancer cases and } \\
24,320 \text { controls. }\end{array}$ & $\begin{array}{l}\text { Colorectal cancer: } \\
\text { Any use, OR=0.91 }(0.86-0.96) \\
\text { Use for } \searrow 6 \text { months, OR=0.92 (0.86-098) }\end{array}$ \\
\hline $\begin{array}{l}\text { Shadman, } \\
2009\end{array}$ & $\mathrm{CC}$ & $\begin{array}{l}\text { Population-based study of } 669 \text { females } \\
\text { with colorectal cancer identified from } \\
\text { Wisconsin cancer reporting system, } \\
\text { and } 1,375 \text { community controls. }\end{array}$ & $\begin{array}{l}\text { Colorectal cancer: } \\
\text { Any use, OR=1.17 }(0.74-1.85) \\
\text { Use for } \geq 3 \text { years, OR=1.27 }(0.68-2.38)\end{array}$ \\
\hline $\begin{array}{l}\text { Singh, } \\
2009\end{array}$ & $\mathrm{RC}$ & $\begin{array}{l}\text { Manitoba's prescribing database used } \\
\text { to compare colorectal cancer } \\
\text { incidence among } 35,739 \text { individuals } \\
\text { regularly dispensed statins and } \\
377,532 \text { non-users. }\end{array}$ & $\begin{array}{l}\text { Colorectal cancer: } \\
\text { Any use, IRR }=1.13(1.02-1.25) \\
\text { Low dose } \geq 5 \text { years, IRR }=0.90(0.54-1.49) \\
\text { High dose } 25 \text { years, IRR }=0.69(0.37-1.28)\end{array}$ \\
\hline $\begin{array}{l}\text { Haukka, } \\
2010\end{array}$ & $\mathrm{RC}$ & $\begin{array}{l}\text { Finnish record linkage study using } \\
\text { national prescribing database. } \\
\text { Incidence of cancer in } 472,481 \\
\text { individuals prescribed statins } \\
\text { compared to an equal number of statin } \\
\text { non-users. }\end{array}$ & $\begin{array}{l}\text { Colon cancer: } \mathrm{RR}=1.01(0.94-1.08) \\
\text { Rectal cancer: } \mathrm{RR}=1.07(0.98-0.1 .17)\end{array}$ \\
\hline $\begin{array}{l}\text { Robertson, }{ }^{66} \\
2010\end{array}$ & $\mathrm{CC}$ & $\begin{array}{l}\text { Danish National Registry of Patients } \\
\text { study. Statin use assessed in } 9,979 \\
\text { colorectal cancer cases and } 99,790 \\
\text { controls. }\end{array}$ & $\begin{array}{l}\text { Colorectal cancer: } \\
\text { Use for } 0-3 \text { years, } O R=0.84(0.75-0.95) \\
\text { Use for } 3-5 \text { years, OR }=0.88(0.74-1.04) \\
\text { Use for }>5 \text { years, OR }=0.95(0.80-1.12)\end{array}$ \\
\hline $\begin{array}{l}\text { Jacobs, }{ }^{77} \\
2011\end{array}$ & $\mathrm{PC}$ & $\begin{array}{l}\text { Association of long-term use of } \\
\text { cholesterol-lowering drugs and } 10 \\
\text { cancers evaluated in Cancer } \\
\text { Prevention Study II Nutrition Cohort } \\
(\mathrm{N}=133,255) \text {. }\end{array}$ & $\begin{array}{l}\text { Colorectal cancer: } \\
\text { Former use, RR }=1.09(0.87-1.36) \\
\text { Current use of }<5 \text { years, RR }=0.93(0.80-1.07) \\
\text { Current use of } \geq 5 \text { years, } R R=0.96(0.82-1.12)\end{array}$ \\
\hline $\begin{array}{l}\text { Lee, }{ }^{69} \\
2011\end{array}$ & $\mathrm{PC}$ & $\begin{array}{l}\text { Association of statin use and } \\
\text { colorectal cancer evaluated in the } \\
\text { Nurses' Health Study }(121,700 \\
\text { women) and Health Professionals } \\
\text { Follow-up Study ( } 51,529 \text { men). There } \\
\text { were } 1818 \text { incident colorectal cancers } \\
\text { during follow-up. }\end{array}$ & $\begin{array}{l}\text { Colorectal cancer: } \\
\text { Current use, } R R=0.97(0.84-1.12) \\
\text { Use for } \searrow \text { years, } R R=0.97(0.75-1.10) \\
\text { Colon cancer: } \\
\text { Current use, } R R=1.10(0.94-1.29) \\
\text { Rectal cancer: } \\
\text { Current use, RR=0.59 }(0.41-0.84)\end{array}$ \\
\hline $\begin{array}{l}\text { Vinogradova, }{ }^{67} \\
2011\end{array}$ & $\mathrm{CC}$ & $\begin{array}{l}\text { Risk of common cancers in relation to } \\
\text { statin use assessed using } 88,125 \text { cases } \\
\text { and } 362,254 \text { controls in the UK } \\
\text { general practice QResearch database. }\end{array}$ & $\begin{array}{l}\text { Colorectal cancer: } \\
\text { Any use, } \mathrm{OR}=1.07(1.00-1.15) \\
\text { Use for }<12 \text { months, } \mathrm{OR}=1.05(0.95-1.17) \\
\text { Use for } \geq 49 \text { months, } \mathrm{OR}=1.23(1.10-1.38)\end{array}$ \\
\hline $\begin{array}{l}\text { Cheng, } \\
2011\end{array}$ & $\mathrm{CC}$ & $\begin{array}{l}\text { Taiwanese population-based study } \\
\text { comprising } 1156 \text { colorectal cancer } \\
\text { cases and } 4624 \text { controls selected from } \\
\text { a national health insurance database. }\end{array}$ & $\begin{array}{l}\text { Colorectal cancer: } \\
\text { Any use, OR=1.09 }(0.94-1.30) \\
\text { Low cumulative use, OR=0.99 }(0.78-1.27) \\
\text { Medium cumulative use, } \mathrm{OR}=1.07(0.78- \\
1.49) \\
\text { High cumulative use, } \mathrm{OR}=1.30(0.96-1.75)\end{array}$ \\
\hline $\begin{array}{l}\text { Simon, } \\
2012\end{array}$ & $\mathrm{PC}$ & $\begin{array}{l}\text { Association of statin use and } \\
\text { colorectal cancer in } 159,219 \text { women } \\
\text { enrolled in Women's Health Study, } \\
\text { where there were } 2000 \text { incident } \\
\text { colorectal cancers. }\end{array}$ & $\begin{array}{l}\text { Colorectal cancer: } \\
\text { Any use, HR=0.99 }(0.83-1.20) \\
\text { Use for } \geq 3 \text { years, HR=0.79 }(0.56-1.11) \\
\text { Lovastatin use, HR=0.62 }(0.39-0.99)\end{array}$ \\
\hline
\end{tabular}


${ }^{a} \mathrm{CC}$, case-control; PC, prospective cohort; RC, retrospective cohort

${ }^{b} \mathrm{CI}$, confidence interval; HR, hazard ratio; IRR, incidence risk ratio; OR, odds ratio; RR, relative risk. Point estimates are adjusted unless stated otherwise. 
Table 2

Observational studies of statins and colorectal adenoma risk

\begin{tabular}{|c|c|c|}
\hline $\begin{array}{l}\text { Author, }{ }^{\text {ref }} \\
\text { Year }\end{array}$ & Study description & Findings: point estimate $(95 \% \text { CI })^{a}$ \\
\hline $\begin{array}{l}\text { Wei, }{ }^{83} \\
2005\end{array}$ & $\begin{array}{l}\text { Secondary analysis in a combined total } \\
\text { of } 2,638 \text { participants of three large } \\
\text { adenoma chemoprevention trials where } \\
8 \% \text { of participants used statins. }\end{array}$ & $\begin{array}{l}\text { Any statin use: } \\
\text { Any adenoma, } \mathrm{HR}=1.03(0.87-1.23) \\
\text { Advanced adenom, } \mathrm{HR}=1.13(0.70-1.81) \\
\text { Multiple adenomas, } \mathrm{HR}=1.25(0.95-1.65)\end{array}$ \\
\hline $\begin{array}{l}\text { Siddiqui, }{ }^{80} \\
2009\end{array}$ & $\begin{array}{l}\text { Endoscopy record-based retrospective } \\
\text { study conducted in } 2,626 \text { veterans } \\
\text { where the prevalence of continuous } \\
\text { statin use was } 35 \% \text {. }\end{array}$ & $\begin{array}{l}\text { Continuous statin use: } \\
\text { Any adenoma, unadjusted } \mathrm{OR}=0.51(0.43-0.60) \\
\text { Advanced adenoma, OR=0.71 }(0.52-0.96)\end{array}$ \\
\hline $\begin{array}{l}\text { Siddiqui, }{ }^{81} \\
2009\end{array}$ & $\begin{array}{l}\text { Analysis of adenoma characteristics } \\
\text { according to LDL reduction in } 231 \\
\text { statin users with recurrent adenomas. }\end{array}$ & $\begin{array}{l}230 \% \text { reduction in LDL vs. }<30 \% \text { reduction: } \\
\text { Advanced adenoma: } \mathrm{OR}=0.47(0.22-0.96)\end{array}$ \\
\hline $\begin{array}{l}\text { Parker-Ray, }{ }^{82} \\
2010\end{array}$ & $\begin{array}{l}\text { Retrospective cohort study using } \\
\text { Veterans Affairs computerized patient } \\
\text { record system. Of } 197 \text { eligible patients, } \\
47 \% \text { received statins during follow-up. }\end{array}$ & $\begin{array}{l}\text { Any statin use: } \\
\text { Any adenoma, } \mathrm{HR}=1.24(0.15-10.4) \\
\text { Log cumulative statin use: } \\
\text { Any adenoma, } \mathrm{HR}=0.90(0.54-1.50)\end{array}$ \\
\hline $\begin{array}{l}\text { Bertagnolli, }{ }^{84} \\
2010\end{array}$ & $\begin{array}{l}\text { Secondary analysis of self-reported } \\
\text { statin use in Adenoma Prevention with } \\
\text { Celecoxib (APC) trial. Statins were } \\
\text { used by } 36 \% \text { of } 2,035 \text { participants. }\end{array}$ & $\begin{array}{l}\text { Any statin use: } \\
\text { Any adenoma, } R R=1.24(0.99-1.56) \\
\text { Statin use for }>3 \text { years: } \\
\text { Any adenoma, RR=1.39, (1.04-1.86) }\end{array}$ \\
\hline
\end{tabular}

${ }^{a} \mathrm{CI}$, confidence interval; HR, hazard ratio; OR, odds ratio; RR, relative risk. Point estimates are adjusted unless stated otherwise. 